\title{
COMPETITIVENESS OF BLUE ECONOMY IN LATVIA
}

\author{
Inese Biuksane \\ Riga Technical University, Latvia \\ inese.biuksane@inbox.lv
}

\begin{abstract}
The aim of the research is to evaluate the competitiveness of the fisheries sector in Latvia. Based on the Model of the factors influencing competitiveness of the fisheries sector cluster developed by the author and methodology of the Index of Fisheries Sector Cluster Competitiveness the author determined the competitiveness level of the fisheries sector in Latvia and identified the spheres influencing competitiveness: facilitating and promising spheres as well as procrastinatory and stagnating spheres, as well as the possibilities of further development were established. The author has developed the evaluation methodology of the Fisheries Sector Cluster Competitiveness that can be used in any country in the fisheries sector (fishery, aquaculture, fish processing) for the evaluation of competitiveness. The elaborated methodology for evaluation of competitiveness may assist the institutions involved in the fisheries' policy formation to work more successfully and improve the common policy in the fisheries sector.
\end{abstract}

Keywords: cluster, competitiveness, fisheries, index, model, Latvia.

\section{Introduction}

The world economy faces changes, mostly related to the processes of globalization, uneven development of the countries, as well as reinforcement of competitiveness. Nowadays, competitiveness of some country's companies more and more determines and influences the development potential of each country. One of the key aims in the development strategy of states, spheres and companies has become ensuring competitiveness [1]. Assessment of competitiveness is a significant element in evaluation of economic performance and sustainability of a sphere and its companies. Analysis of competitiveness allows impartial evaluation of the most competitive advantages of the sector's cluster in comparison with sectors of other countries, thus allowing a better understanding of the need in structural reforms and choice of priorities [2].

In the development of Latvian economy, the fisheries have always played a significant role, especially in the development of the Baltic Sea and Riga Gulf coastline areas. In Latvia the fisheries sector has not only a long-standing history and traditions, but also an internal potential of selfdevelopment and the ability to produce a competitive product in the world market. Using the advantage of the support opportunities provided by the EU financial instruments and participating in the EU Common fisheries policy creation, Latvian fisheries sector obtains wide possibilities to facilitate its growth and competitiveness. Consequently, the assessment of the sector cluster competitiveness plays a significant role in facilitation of the fisheries sector development.

Research aim - to evaluate the competitiveness of the Latvian fisheries sector. To reach the aim, the following work tasks were set: 1) to elaborate the methodology for competitiveness of the fisheries sector cluster; 2) to evaluate the competitiveness of the Latvian fisheries sector, identifying the spheres ensuring competitiveness.

The novelty of the research - developed evaluation methodology of the Fisheries Sector Cluster Competitiveness that can be used in the fisheries sectors (fishery, aquaculture, fish processing) for the assessment of competitiveness. The elaborated methodology for evaluation of competitiveness may assist the institutions involved in the fisheries' policy-making to work more successfully and improve the common policy in the fisheries sector.

The qualitative and quantitative research methods were used in the study, including the general scientific research methods, statistical research methods, mathematical methods and sociological research methods. Microsoft Excel was used in the processing and analysis of the study results.

\section{Materials and methods}

The Fisheries sector cluster is cooperation network of similar or associated companies and institutions operating in the sector, which is located in specific geographic territory (Figure 1). Within the framework of this network, competitiveness and development of every separate company and, respectively, of all sector is facilitated by common cooperation. Competitiveness of the Fisheries 
Sector Cluster is affected by the various internal and external social, economic, political, natural and cultural environmental factors (including random events) and the ability to adapt them, as well as formation of mutual interaction and cooperation forms and relationship among affiliated companies and support infrastructure institutions [2].

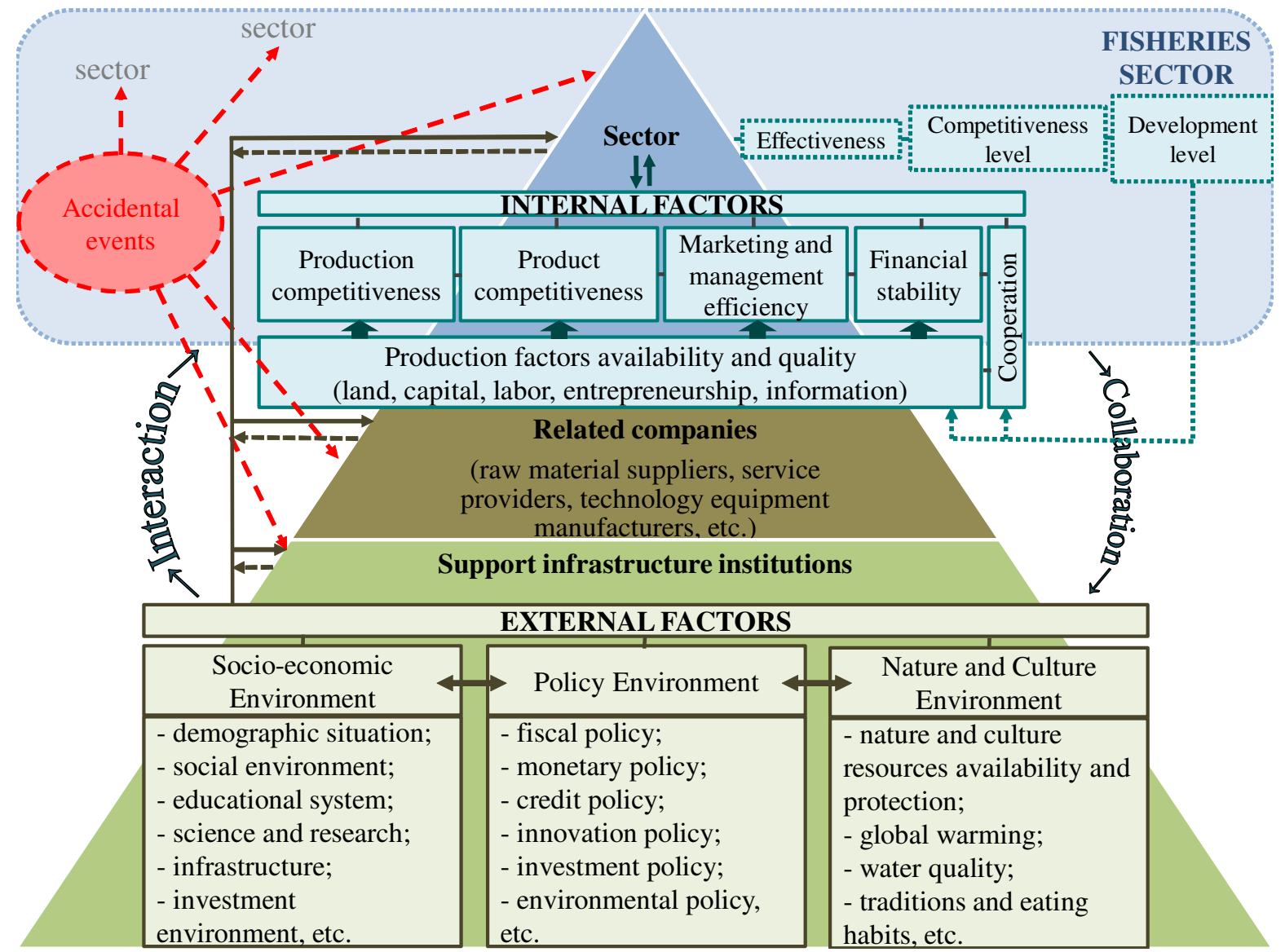

Fig. 1. Model of the Factors Influencing Competitiveness of the Fisheries Sector Cluster [2]

The sector competiveness is the ability to sell higher quality product (goods and services) in markets more efficiently than domestic and international competitors are able to do it [3]. The competitive advantage of the Fisheries Sector Cluster appears in the efficiency and its growth that is crucial for the sector competitiveness and its level of development. The competitive advantage allows the fisheries companies to be different from the rest of its competitors, thus giving the opportunity to be a leader. It should be taken into account that competitive advantage should not only be maintained, but also regularly revised, analysed and improved not to provide the competitors with the possibilities of growth in the environment of fierce competition. In this case sector companies must be dynamic, being in a continuous process of cognition and development; thus, companies will be able not only to increase their own competitiveness, but also competitiveness of the entire sector in the long term [2].

Related companies and the spheres included in support infrastructure depend on the development of leading companies in a sphere. When leading companies of a sphere are developing, both related companies and the spheres included in support infrastructure have benefit. In the environment of the cluster, integrated long-term development of the companies may be observed at horizontal and vertical level; as a result, not only competitiveness of the companies in a sphere increases, but also competitiveness of a region and country does [3]. The competitiveness of a country directly depends on the competitiveness of every company working in a specific economic sector. The more competitive companies in a certain sector, the more competitive the corresponding sphere and consequently the more competitive the country at the world level [1; 4-6].

The Index of the Fisheries Sector Cluster Competitiveness that was created basing on the author's developed Model of the factors influencing competitiveness of the fisheries sector cluster allows to assess and analyze the competitiveness of the fisheries sector in time and space. The Index of the 
Fisheries Sector Cluster Competitiveness is a tool for assessing the fishery, aquaculture and fish processing competitiveness, which reflects the factors influencing the competitiveness of the fisheries sector at the level of microeconomics and macroeconomics (Figure 2).

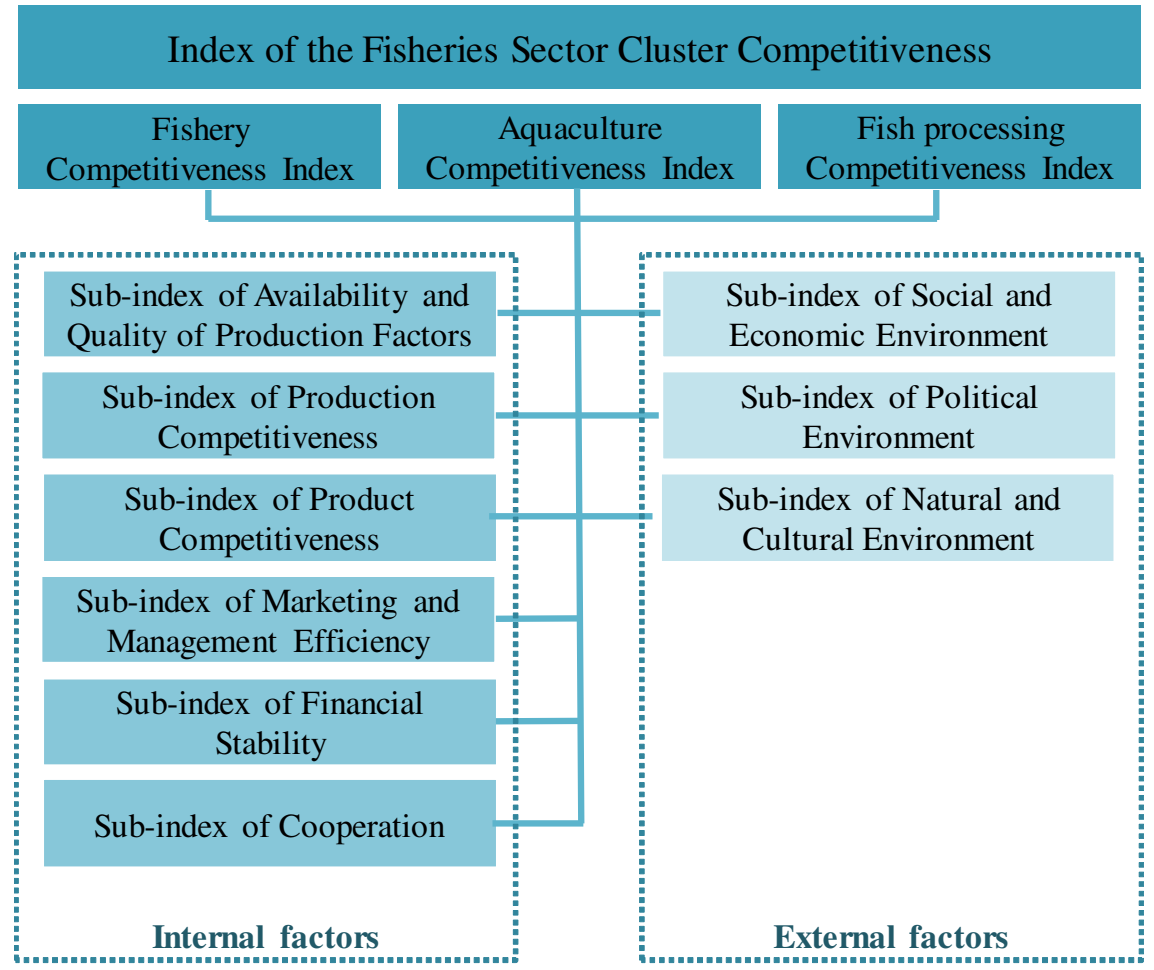

Fig. 2. Framework of the Index of the Fisheries Sector Cluster Competitiveness [7]

The Fisheries Sector Cluster Competitiveness in the microeconomic level is described by a number of sub-indexes, which reflect the ongoing processes within fisheries sector that the sector is able to influence and control, thus affecting its competitiveness and potential for development. In turn, the Fisheries Sector Cluster Competitiveness in the macroeconomic level is described by the subindexes, which reflect the macroeconomic environment and the quality of work of the fisheries sector and its companies. The fisheries sector is not in a position to significantly influence and control this environment. It should be noted that sub-indexes are not independent - they supplement and facilitate each other, consequently, they must be analysed complexly.

Index of the Fisheries Sector Cluster Competitiveness is complex indicator - it consists of Fishery, Aquaculture and Fish processing Competitiveness Index. The Competitiveness Index of Fishery, Aquaculture and Fish processing is calculated on the basis of several sub-indexes. The subindexes are expressed in terms of function from their relative weights and normalized values of the indicators influencing the competitiveness. The normalization of indicators is carried out on the basis of min-max algorithm in values from -5 to 5 . In order to carry out the evaluation of the Fisheries Sector Cluster Competitiveness at the level of microeconomics the author selected in general 22 indicators [2] and more than 35 sub-indicators, as well as used several additional indicators. Indicators are chosen according to the Model of the factors influencing competitiveness of the fisheries sector cluster and the main conditions of the indicator selection (including statistical data availability and quality) [8].

The Index of the Fisheries Sector Cluster Competitiveness does not offer a complex solution system for advancement of the competitiveness - it offers an opportunity to evaluate the competitiveness of the fisheries sector in the course of time, identifying the spheres ensuring competitiveness. The Index of Competitiveness of the Fisheries Sector Cluster can be used as a tool for assessment of the fishery, aquaculture and fish processing competitiveness. The index may assist the institutions involved in the fisheries' policy formation to work more successfully and improve the common policy in the fisheries sector [2]. 
The evaluation methodology of the Fisheries Sector Cluster Competitiveness developed by the author can be used to evaluate competitiveness of the fisheries sector and its sectors of any country. On further research the author evaluated the competitiveness of the Latvian fisheries sector and the spheres that currently ensure it.

\section{Results and discussion}

The Index of the Fisheries Sector Cluster Competitiveness during the period from 2005 to 2014 for the Latvian fisheries sector was approximately 0.27 . The level of competitiveness of the fishery sector in this period is evaluated as medium-high (1.59), but the level of competitiveness of the aquaculture sector - medium-low (-1.23). In turn, the level of competitiveness of the fish processing sector similarly as in the fishery sector is evaluated as medium-high (0.46), except for the year $2010-$ time after socio-economic crisis in Latvia, when competitiveness of the fish processing sector was at its lowest point (respectively: -0.15) (Figure 3).

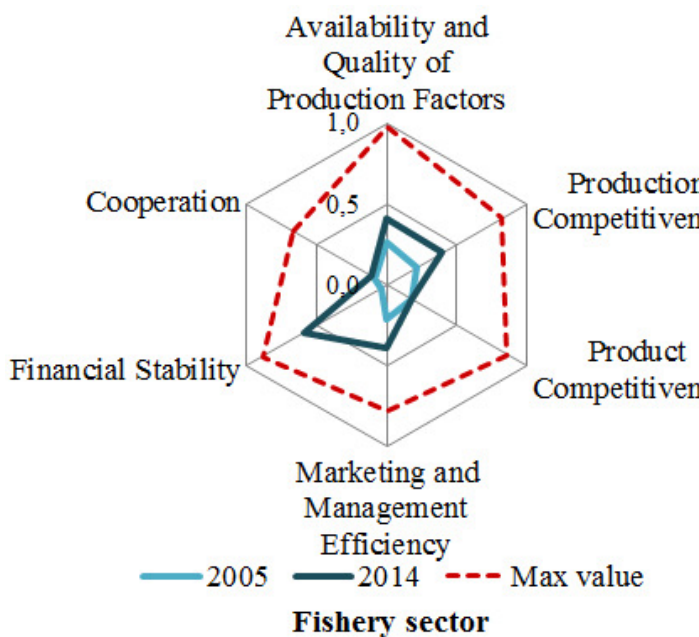

Availability and Quality of
Availability and Quality of Production Factors

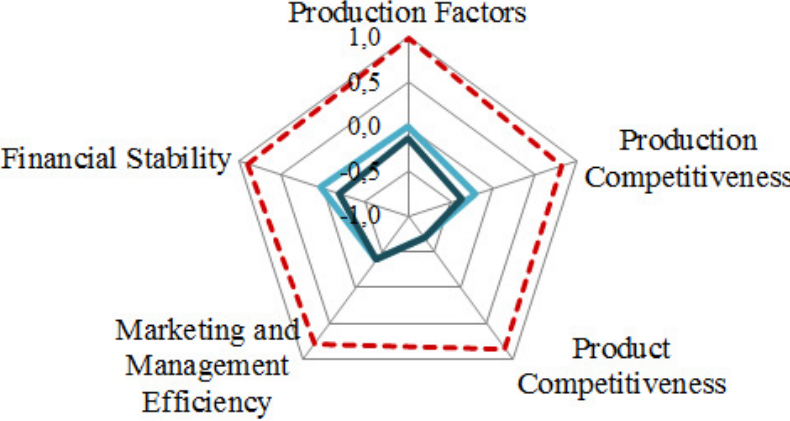

-2005 -2014 --- Max value

Aquaculture sector

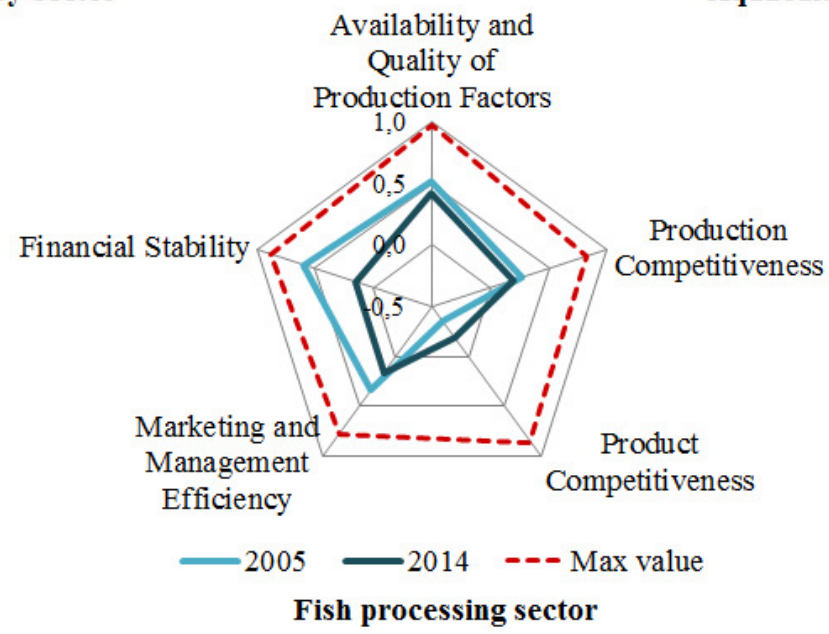

Fig. 3. Competitiveness assessment of the Latvian fisheries sector according to the sphere of activity in 2005 and 2014 (value of sub-indexes), calculated and created by the author according to [9-11]

During this period the competitiveness of the Latvian fishery sector increased by $108 \%$ (from 1.00 in 2005 to 2.07 in 2014), in turn, the competitiveness of the aquaculture sector decreased by $40 \%$ (from -1.25 in 2005 to -1.75 in 2014), and the competitiveness of the fish processing sector decreased by $-45 \%$ (from 1.36 in 2005 to 0.74 in 2014). The competitiveness of the Latvian fisheries sector and its sectors was affected by changes in the availability and quality of production factors, the production and product competitiveness, the marketing and management efficiency, as well as changes in the financial stability and cooperation.

The facilitating spheres of the fishery sector competitiveness are the financial stability, the marketing and management efficiency, the availability and quality of production factors, the 
production competitiveness as well as the cooperation. Although product competitiveness in the fisheries sector may be evaluated as medium high, it is currently in stagnation and it is in a transition period between facilitating and promising sphere (Figure 4).
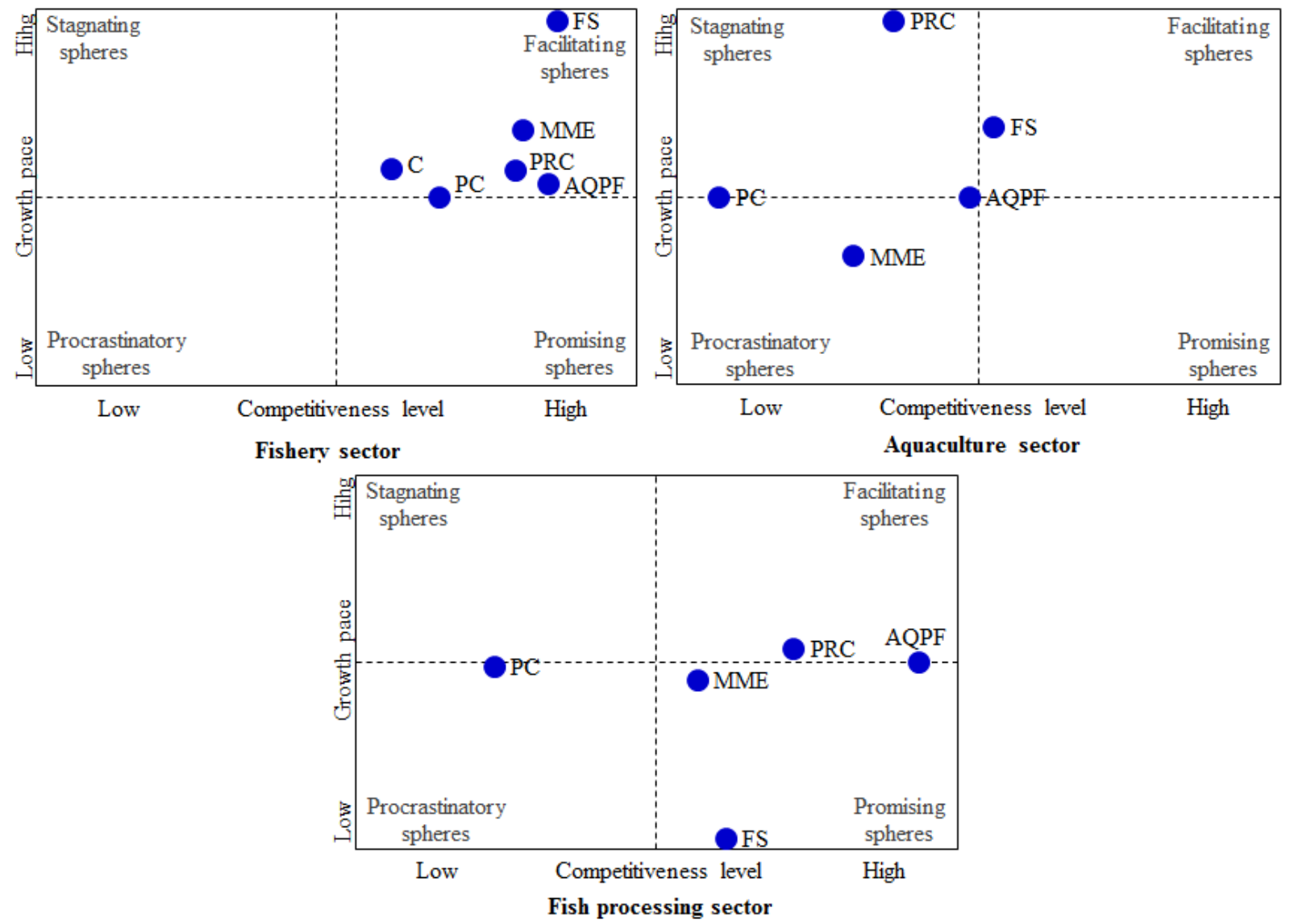

Fig. 4. Ensuring spheres of the Latvian fisheries sector competitiveness, calculated and created by the author according to [9-11]

where $A Q F P-$ Availability and Quality of Production Factors;

$P R C$ - Production Competitiveness;

$P C$ - Product Competitiveness;

$M M E$ - Marketing and Management Efficiency;

$F S$ - Financial Stability;

$C$ - Cooperation.

In turn, the facilitating sphere of the aquaculture sector competitiveness is the financial stability, but the procrastinatory sphere - the marketing and management efficiency, and the stagnating sphere the production competitiveness. Availability and quality of production factors in the aquaculture sector may be evaluated as medium low, but product competitiveness - as very low, which is currently in stagnation stage between procrastinatory and stagnating spheres.

The facilitating spheres of the fish processing sector competitiveness include the availability and quality of production factors and the production competitiveness, the promising spheres include the marketing and management efficiency and the financial stability, but the procrastinatory sphere - the product competitiveness. Cooperation is missing in the aquaculture and fish processing sectors unlike the fishery sector, these sectors do not have any established producer organization.

The companies that operate in the Latvian fisheries sector and the representatives of the institutions involved in the fisheries sector policy-making and implementation believe that the growth of the sector competitiveness can be promoted by the implementation of a number of interrelated and subordinated measures (Table 1). 
Promoting measures of the Latvian fisheries sector competitiveness (response rate, \%), calculated and created by the author according to [12]

\begin{tabular}{|l|c|c|c|c|c|c|}
\hline \multirow{2}{*}{ Measures } & \multicolumn{2}{|c|}{ Fishery sector } & \multicolumn{2}{c|}{ Aquaculture sector } & \multicolumn{2}{c|}{ Fish processing sector } \\
\cline { 2 - 7 } & Companies & Experts & Companies & Experts & Companies & Experts \\
\hline $\begin{array}{l}\text { Employee training and } \\
\text { qualification }\end{array}$ & 0 & 22 & 80 & 49 & 0 & 18 \\
\hline Cost optimization & 60 & 59 & 80 & 44 & 60 & 76 \\
\hline Innovative technologies & 20 & 40 & 80 & 46 & 100 & 35 \\
\hline $\begin{array}{l}\text { Production of high added } \\
\text { value }\end{array}$ & 60 & 37 & 60 & 59 & 100 & 41 \\
\hline Marketing activities & 0 & 21 & 60 & 41 & 80 & 12 \\
\hline Export & 40 & 37 & 40 & 54 & 80 & 47 \\
\hline Cooperation & 60 & 37 & 100 & 51 & 20 & 12 \\
\hline $\begin{array}{l}\text { Learning and exchange } \\
\text { experience }\end{array}$ & 0 & 32 & 60 & 49 & 0 & 18 \\
\hline $\begin{array}{l}\text { EU financial instruments } \\
\text { and state support }\end{array}$ & 60 & 70 & 80 & 77 & 80 & 47 \\
\hline $\begin{array}{l}\text { Cooperation with } \\
\text { scientific institutions }\end{array}$ & 0 & 41 & 80 & 54 & 80 & 6 \\
\hline Other & 20 & 8 & 20 & 5 & 40 & 12 \\
\hline
\end{tabular}

Note: Companies: Latvian fisheries sector (fishery, aquaculture and fish processing) companies. Experts - the representatives of the institutions involved in the Latvian fisheries sector policy-making and implementation.

The Latvian fishery sector competitiveness can be promoted by an efficient and rational use of EU financial instruments and support options provided by the state, making a cost optimization, as well as manufacturing innovative products of good quality with a high added value and creating a strong cooperation (particularly coastal fishery). The Latvian aquaculture sector competitiveness can be promoted by creating a strong cooperation (producer organizations) that are currently missing in the aquaculture sector, and efficient and rational use of the EU financial instruments and support options provided by the state. In turn, the Latvian fish processing sector competitiveness can be promoted by using innovative technologies in the production process and producing innovative fish products of good quality with a high added value, as well as making a regular cost optimization. According to the opinion of the companies and the representatives of the institutions involved in the fisheries sector policy-making and implementation the competitiveness of the Latvian fisheries sector and its sectors can be also promoted by other measures.

Although the measures proposed by the fisheries companies and the representatives of the institutions involved in the fisheries sector policy-making and implementation are focused on promotion of the Latvian fisheries sector and its sectors' competitiveness and they are considered useful, however, the author believes that the promoting measures should be structured and implemented according to the chosen development strategy and investment policy. There are several types of strategies $[13 ; 14]$, however, in the opinion of the author, to facilitate the competitiveness of the Latvian fisheries sector a strategy of corresponding approach should be developed.

The spheres and their factors that are currently ensuring the Latvian fisheries sector competitiveness can be used as a basis for the development of a specific strategy and the implementation of a proper investment policy. Taking into account that the fishery and fish processing sectors are more competitive and have more facilitating and promising factors and less procrastinatory and stagnating factors, while the aquaculture sector has more procrastinatory and stagnating factors and less facilitating and promising factors, the development strategy and investment policy of the Latvian fisheries sector should be different, yet interrelated and subordinate (Table 2).

In the author's opinion, the most appropriate promotion strategy of the fisheries sector competitiveness is an improvement strategy, which foremostly provides for implementation of measures to strengthen spheres facilitating competitiveness. In respect of the most appropriate promotion strategy of the aquaculture sector competitiveness the author proposes enlargement 
strategy, which foremostly provides for implementation of measures to strengthen the spheres stagnating competitiveness. In turn, concerning the most appropriate promotion strategy of the fish processing sector competitiveness the author proposes the development strategy, which foremostly provides for implementation of measures to strengthen the spheres promising competitiveness.

Table 2

Promotion options of the Latvian fisheries sector competitiveness (created by the author)

\begin{tabular}{|c|c|c|c|c|}
\hline \multirow{2}{*}{ Competitiveness } & \multicolumn{5}{|c|}{ Strategy type } \\
\cline { 2 - 5 } & $\begin{array}{c}\text { Penetration } \\
\text { strategy }\end{array}$ & $\begin{array}{c}\text { Enlargement } \\
\text { strategy }\end{array}$ & $\begin{array}{c}\text { Development } \\
\text { strategy }\end{array}$ & $\begin{array}{c}\text { Improvement } \\
\text { strategy }\end{array}$ \\
\hline$C_{L(-0<)} ; G_{P(0 \leq)}$ & - & - & - & - \\
\hline$C_{L(-0<)} ; G_{P(>0)}$ & - & $\begin{array}{c}\text { aquaculture } \\
\text { sector }\end{array}$ & - & - \\
\hline$C_{L(>0)} ; G_{P(0 \leq)}$ & - & - & $\begin{array}{c}\text { fish processing } \\
\text { sector }\end{array}$ & - \\
\hline$C_{L(>0)} ; G_{P(>0)}$ & - & - & - & fishery sector \\
\hline
\end{tabular}
where $C_{L}-$ competitiveness level;
$G_{P}$ - growth pace.

To promote the potential of the Latvian fisheries sector it is important to create a successful cooperation among the representatives of the institutions involved in the fisheries sector policymaking and implementation and the sector companies. Well thought-out and elaborated development strategy of the Latvian fisheries sector and appropriately chosen investment policy can promote the development and competitiveness of the sector and its sectors.

\section{Conclusions}

Competitiveness of the Fisheries Sector Cluster is affected by the availability of the production factors and the efficiency of their usage, various internal and external social, economic, political, natural and cultural environmental factors (including random events) and the ability to adapt them, as well as formation of mutual interaction and cooperation forms and relationship among affiliated companies and support infrastructure spheres. Fisheries sector's of Latvia have different facilitating, promising, procrastinatory and stagnating spheres influencing competitiveness, what is the determinative in the choice of a specific development strategy. To advance the competitiveness of the fishery sector an improvement strategy is recommended, of the aquaculture sector - enlargement strategy, whereas, of the fish processing sector - development strategy. Implementation of different strategies may facilitate the growth of the Latvian fisheries sector's competitiveness.

\section{References}

1. Škapars R., Šumilo Ē. Latvijas ekonomikas un sabiedrības pārstrukturizācijas ietekme uz uzņēmējdarbības konkurētspēju un iedzīvotāju dzīves kvalitāti (Impact of Latvian Economy and Society Restructuring on the Competitiveness of Companies and life Quality of the Population). Rīga: LU Akadēmiskais apgāds, 2006. 339 lpp. (In Latvian)

2. Biukšāne I. Index of the Fisheries Sector Cluster Competitiveness: Internal factors. SGEM2016 Conference Proceedings, August 22-31, 2016, Albena, Bulgaria, pp. 347-354. Doi: 10.5593/SGEMSOCIAL2016/B24/S07.046

3. Biukšāne I. Model of the Factors Influencing Competitiveness of the Latvian Fisheries Sector Cluster. Journal Economics and Business, Vol. 28, 2016, pp. 76-82. doi: 10.1515/eb-2016-0011.

4. Deņisovs M., Judrupa I. Reğionu attīstības un konkurētspējas novērtēšana (Assessment of Regional Development and Competitiveness). Rīga: RTU Izdevniecība, 2008. 72 lpp. (In Latvian)

5. Ministry of Welfare. Latvijas un tās reǵionu darba tirgus specifiskās problēmas (Specific Problems of Labour Market in Latvia and its Regions). Jelgava: Jelgavas tipogrāfija, 2007. 228 lpp. (In Latvian)

6. Бочкова С. Основные проблемы и возможности практической оценки конкурентоспособности предприятия (Basic Problems and Opportunities of Practical 
Assessment of Company Competitiveness) [online] [05.01.2016.]. Available at: http://koet.syktsu.ru/vestnik/2009/2009-1/2/2.htm (In Russian).

7. Biukšāne I. Index of the Fisheries Sector Cluster Competitiveness. Journal of System and Management Sciences, Vol. 5, Issue 4, 2015, pp. 63-83.

8. Biukšāne I., Judrupa I. Evaluation of competitiveness of the fisheries sector cluster. International Scientific Conference "Research for Rural Development 2016" Proceedings, May 18-20, 2016, Jelgava, Latvia, pp. 238.-245.

9. Central Statistical Bureau database [online] [01.11.2016.]. Available at: http://data.csb.gov.lv/pxweb/lv/?rxid=cdcb978c-22b0-416a-aacc-aa650d3e2ce0

10. Latvian Fisheries integrated control and information system "LFICIS" database [online] [01.11.2016.]. Available at: https://lzikis.zm.gov.lv/Account/LogOn

11. Producer organizations. Latvian Producer organizations data from 2004-2016 (restricted access data).

12. Biukšāne I. The results of the interviews given by the representatives of the institutions involved in the Latvian fisheries sector policy-making and implementation and the fisheries sector companies' survey results (answers submitted 5 experts and 119 or $36 \%$ fisheries sector companies in the period from 18.03.2016. till 13.04.2016.) (restricted access data).

13. Kersan-Škabić I., Tijanić L. The Challenges of Competitiveness in Southeast European Countries. South East European Journal of Economics and Business, Vol. 4, Issue 2, 2009, pp. 23-37. doi: 10.2478/v10033-009-0011-6.

14. Rauch P. SWOT analyses and SWOT strategy formulation for forest owner cooperation in Austria. European Journal of Forest Research, Vol. 126, Issue 3, 2006, pp. 413-420. doi: 10.1007/s10342-006-0162-2. 